\title{
How STEM Academy Teachers Conceptualize and Implement STEM Education
}

\author{
Teruni Lamberg ${ }^{1}$, Nicole Trzynadlowski \\ The University of Nevada, Reno, USA
}

\begin{abstract}
STEM (science, technology, engineering and mathematics) education has been gaining increasing nationwide attention. While the STEM movement has ambitious goals for $k-12$ education, a lack of shared understanding exists of what STEM is as well as how to implement STEM in the elementary classroom. This study investigates how seven elementary teachers in three STEM academy schools conceptualize and implement STEM in their classrooms. Teacher interviews were conducted. The findings reveal that the majority of teachers believe that STEM education involves integrating STEM subject areas. STEM activities consisted of student-led research and reading activities on STEM topics. Two teachers described STEM as involving "hands-on" science activities. Teachers at each STEM academy school conceptualized and implemented STEM differently. How STEM was implemented at each school was based on how teachers interpreted STEM and the resources they had access to. The STEM coaches played a central role in supporting the elementary teachers to plan and implement lessons. Teachers relied on them for ideas to plan and teach STEM lessons. The results of this study indicate that as more schools embrace the STEM movement, a unified understanding and resources are needed to support teachers.
\end{abstract}

Keywords: STEM Schools; Lesson Planning; Learning

This study investigates how STEM academy schools in a western state interpret and implement STEM education. Across the country, there are various elementary schools which have transformed into STEM academies. The goal of these STEM academies is largely consistent-to "prepare students to communicate and compete as global thinkers within the community using Science, Technology, Engineering, and Mathematics" (Bluford STEM Academy website, 2013, "STEM (2)", para.1) through "STEM learning environments [that] are fully integrated verses the typical instructional structure of subjects being taught in isolation." (West Hills STEM Academy website, 2013, "How is STEM learning environment different from your average elementary and middle level classroom?" para.1). This study specifically seeks to understand how teachers in STEM schools interpret what the word "STEM" represents and how they implement STEM in the classroom.

\section{Review of Relevant Literature}

As the United States economy is becoming more diversified and reliant on innovation, Science, Technology, Engineering, and Math (STEM) skills and proficiency are increasingly needed for competition and advancement. American students are less competitive with other countries in STEM fields, placing 17th in science achievement and 25th in math (Hanushek, Peterson, \& Woessmann, 2011). There is a persistent dialogue on emphasizing the teaching of STEM in schools due to a growing supply of high-skill STEM jobs expected to outpace non-STEM jobs in the next decade (National Math and Science Initiative, 2012). Ultimately, a broader goal underlying the STEM movement is to increase STEM literacy. STEM literacy is defined as "the knowledge

\footnotetext{
${ }^{1}$ Corresponding author. Teruni Lamberg, College of Education, University of Nevada, Reno, 1664 N. Virginia Street, MS 280 , Reno, NV 89557 Terunil@unr.edu

Lamberg,T. \& Trzynadlowski, N. (2015). How STEM Academy teachers conceptualize and implement STEM education. Journal of Research in STEM Education. 1(1), 45-58
} 
and understanding of scientific and mathematical concepts and processes required for personal decision making, participation in civic and cultural affairs, and economic productivity for all students" (National Research Council of the National Academies of Science, 2011). With the rapid changes in society and the 21 st century affecting everything from health to technology, STEM skills help individuals make more informed decisions.

With this new movement in education to focus more on STEM, educators are questioning what is STEM and how exactly to teach STEM. Jonathan Gerlach, an Albert Einstein Distinguished Educator who works on federal education policy in Washington, D.C., asked several questions pertinent to the focus of this study in a report for the National Science Teachers Association news digest in 2012. Gerlach asked whether science alone or mathematics by itself can be considered STEM education; whether using technology is sufficient in covering the 'T' in STEM (2012). He also pointed out that asking a number of teachers to define STEM will likely bring about many different answers.

\section{Conceptualizing and Defining STEM Education}

Many educators approach STEM education with uncertainty because no single definition of STEM education exists, and many "do not have an interdisciplinary understanding of STEM" (Breiner, Harkness, Johnson, \& Koehler, 2012, p. 6). The confusion does not solely lie with general elementary school teachers, but also with some STEM teachers. These teachers do not share a unified understanding or definition of STEM (Breiner et al., 2012).

Brown, Brown, Reardon, and Merrill (2011) wrote about the lack of understanding of STEM education in schools. They define STEM education using a 2009 formal definition outlined by one of the authors, Dr. Merrill. Merrill is a Professor of Technology at Illinois State University and has previously written extensively on STEM and specifically technology. He defines STEM education as:

[A] standards-based, meta-discipline reading at the school level where all teachers, especially science, technology, engineering, and mathematics (STEM) teachers, teach an integrated approach to teaching and learning, where discipline-specific content is not divided, but address and treated as one dynamic, fluid study (Brown et al., 2011, p. 6).

This definition mentions the use of an integrated approach, which refers to combining subjects rather than teaching them separately. The National Science Teachers Association defines STEM education as:

[The] preparation of students in competencies and skills in the four disciplines (science, technology, engineering, and math). A successful STEM education provides students with science, math, and engineering/technology in sequences that build upon each other and can be used with real-world applications (Eberle, 2010, "Why STEM is important" para. 3).

This definition does not outline an approach or design for implementation of STEM education as Dr. Merrill's definition does, but emphasizes the use of "real-world applications".

The National Education Association (NEA) is the largest professional organization and labor union in the United States. But the NEA does not seem to have its own definition of STEM education. Rather, the NEA has resources for teachers to teach STEM and refers to STEM education in general terms as it is referred to by other organizations. The lack of a clear definition for STEM is likely one reason why teachers have different conceptualizations and approaches for teaching STEM.

The Committee on Science, Technology, Engineering, and Math Education (CoSTEM) of the National Science and Technology Council crafted a formal definition of STEM education to establish federal guidelines and to aid in the federal grants process. In 2011, the committee published a report indicating that agencies use different criteria for describing a "STEM education program." STEM education is defined by CoSTEM as "ed- 
ucation that is primarily focused on physical and natural sciences, technology, engineering, and mathematics disciplines, topics, or issues (including environmental science education or environmental stewardship)" (2011, p. 5). CoSTEM further identifies eight possible primary objectives of STEM education in the form of learning, engagement, pre- and in-service education/education leader performance, postsecondary STEM degrees, STEM careers, STEM system reform, institutional capacity, and education research and development (2011). Again, no approach or teaching methods are outlined by CoSTEM's definition, but those elements would likely be irrelevant to the committee's purpose for crafting a definition of STEM education.

\section{STEM Programs in the United States}

The Conceptual Framework for New Science Education Standards by the National Research Council of the National Academies of Science (2011) cites research studies which suggest that effective STEM-based instruction depends on teachers who understand their students' strengths and weaknesses and are able to actively engage students in the STEM subjects with concepts requiring problem-solving thinking. Most of the STEM-focused schools have curricula which are inquiry-based and problem-centered; assessments are thus aligned to reflect students' knowledge, and can be informal, such as classroom observations by trained staff or external reviewers (National Research Council et al., 2011).

The Committee on Highly Successful Schools or Programs in k-12 STEM Education (2011) identified three types of STEM-focused schools which can serve as models for schools attempting to implement STEM education: selective STEM schools, inclusive STEM schools, and schools with STEM-focused career and technical education (CTE). These schools were identified as successful by the Committee and the National Research Council based on varying factors since each school has its own data on student outcomes and returns on investment. However, the schools' overall impacts on student achievement and motivation were largely taken into consideration. The Committee also notes that these schools' programs can be modified for any k-12 school (2011).

Selective STEM schools "organize around one or more of the STEM disciplines and have selective admissions criteria," enrolling a small number of students who have demonstrated talent and initiative in the STEM subjects (National Research Council et al., 2011, p. 8). Selective STEM schools tend to be high schools and they prepare students to earn STEM degrees or careers in STEM fields. These schools share the following qualities: teachers with degrees in one or more STEM subjects, advanced curricula, laboratory equipment for the regular use by students, offer students apprenticeships with scientists, and provide staff with professional development (U.S. Department of Labor, 2007). There are 90 selective STEM schools in the country. Studies show that students who are involved in programs such as those offered by selective STEM schools are more likely to complete a STEM major (Stone, Alfeld \& Pearson, 2008).

The second type of STEM-focused school is an inclusive STEM school. These also organize around one or more of the STEM subjects, but do not have selective criteria so they serve a wider population (Young, House, Wang, Sindleton, \& Klopfenstein, 2011). Inclusive STEM schools offer experiences in line with the understanding that "math and science competencies can be developed, and that students from traditionally underrepresented subpopulations need access to opportunities to develop these competences to become full participants in areas of economic growth and prosperity" (National Research Council et al., 2011, p. 11). Records of student involvement and success, particularly those from the state of Texas, indicate that students in inclusive STEM schools score higher on standardized science and mathematics exams, attend school more frequently and regularly, and take more advanced courses than students in other schools (Young et al., 2011).

The third type is a school with a STEM-based CTE. These enroll high school students and prepare them for STEM-related careers with a larger goal of dropout prevention (Stone et.al. 2008). STEM-based CTE typically has programs which allow students to engage in practical applications of STEM subjects in order to grasp an understanding of different types of STEM jobs. 
The National Research Council and the Committee on Highly Successful Schools or Programs in k-12 STEM Education (2011) note that STEM instruction, as seen in the three types of STEM-focused schools, remain in the minority. Heavy focus on STEM education is still not the norm in today's schools. Teachers have little understanding of how to overcome the challenges in implementing a successful STEM curriculum that both aligns with standards and is feasible given economic and time restraints, and the teacher's level of knowledge. These STEM schools are typically high schools, not elementary schools. There are far fewer elementary STEM academies across the country to be able to describe the organization of their schools and STEM curricula in detail. Therefore, there is a need to understand what it means to prepare students for STEM education at the elementary school level.

\section{Theoretical Framework Guiding the Study}

Across the country, there are various elementary schools, which have transformed into STEM academies. The goal of these STEM academies is largely consistent-to "prepare students to communicate and compete as global thinkers within the community using Science, Technology, Engineering, and Mathematics" (Bluford STEM Academy website, 2013, "STEM (2)", para.1 ) through "STEM learning environments [that] are fully integrated verses the typical instructional structure of subjects being taught in isolation." (West Hills STEM Academy website, 2013, "How is STEM learning environment different from your average elementary and middle level classroom?" para.1).

Very little research exists on how schools interpret and implement STEM education. This may be due to the overall lack of a coherent definition of STEM education by major education organizations. Therefore, there is a need to understand how schools interpret and implement STEM. This study attempts to understand how STEM academy schools in a western state interpret and implement STEM education. The following questions are investigated: How do STEM academy teachers define and implement STEM education? What resources do STEM teachers use to aid in the implementation of STEM education?

\section{Methodology}

\section{Context, Participants and Intervention}

A large district in a western state received Title 1 funding to create STEM academies to improve learning and academic performance. The district has over 30,000 elementary school students who are racially and economically diverse. It has 63 elementary schools and three of which are STEM academies. The three STEM academies in this district received a School Improvement Grant (SIG) to aid in the transformation of their curricula and infrastructure through the ability purchase new resources in order to support STEM education. As per the grant fulfillments, the new curriculum must have an "emphasis on problem solving, technology integration, common core standards, and science and engineering emphasis to promote a rigorous, challenging academic program for all students" (School One, 2012).

These STEM academies can be considered inclusive STEM schools as defined by the National Research Council (2011) because they attempt to serve all their students at these schools. Two of the three STEM academies have a definition of STEM education on their websites, which offers some insight into these schools perception of STEM education. School One defines STEM as:

Science - a way of learning and discovering about our natural world; Technology - the making and use of tools, machines, techniques, etc. to achieve a goal or function; Engineering - don't let the 'E' scare you - science and math to benefit humans; Math - study of quantity, structure, space, and change (School One website, 2013).

School Two uses its school purpose to outline STEM education: 
STEM is the use of integrative and thematic units of instruction to logistically tie-in the often neglected science and technology components of sound teaching" (School Two website, 2012).

\section{Data, Data Sources and Data Collection}

This study investigated how teachers interpret and implement STEM in three STEM elementary schools in the western U.S. Therefore, seven teachers from these three STEM schools were interviewed after school. An e-mail was sent to all teachers in the STEM schools requesting interviews. Seven teachers volunteered to be interviewed. Teachers were individually interviewed after school. The interview questions were based on the following categories: STEM - Teacher Perception, STEM Activities, STEM - Student Perspective, STEM Planning, STEM Resources, and STEM Support. The data was further coded into categories as represented in table one for further analysis. (see Appendix B for Interview Questions.)

\section{Data Analyses}

The data was systematically analyzed and coded for themes using Strauss and Corbin Grounded Theory approach (1998). Open coding was used to identify key words or phrases that embodied each teacher's definition and implementation of STEM education. Key words and phrases were underlined or highlighted, and subsequently categorized more broadly to then identify patterns or differences in teacher responses. The underlined phrases represent repetition of codes across the data. And because the main research question dealt with the definition and implementation of STEM education by STEM academy teachers, the researcher compared the codes within each interview question category for each individual teacher to identify any relationships or influences on such things as STEM activities or STEM planning. The similarities found across the data and the analysis of codes within categories allowed for the emergence of theories to answer the research questions (see Appendix A for sample coding example).

\section{Results}

\section{STEM: Teacher perception}

The STEM academy teachers were first asked to define STEM education. They used several common key words and gave broad definitions of STEM education. All seven teachers said the word 'integration' many times throughout their individual interviews. Six out of the seven teachers specifically indicated "reading about STEM or STEM topics" as an integral part of their STEM curricula, exemplified in this response by a teacher from School One:

We separate our subjects throughout the day, but as I said before you can find all aspects of STEM throughout the day, so it's more broad fields. And while we say it is Reading time between 9:00-10:30, you could find a lot of STEM going on as well as we read about science, technology. (Teacher B, School One, Interview, Jan. 17, 2013)

Further clarification from other teachers also indicated that students read about STEM during reading blocks, and even during designated science times, and that the teachers indicate this qualifies as STEM education. This theme, "integration of STEM content areas through reading," explains teacher perceptions of STEM education more broadly. It also aligns with most modern conceptions of STEM education that include integration or the teaching of the "integrated disciplines as one cohesive entity" (Breiner et al., 2012, p. 5).

When asked to define STEM education, most of the teachers defined the acronym "STEM," but gave little insight into what STEM education is and how it is implemented, aside from mentioning integration of the subjects into the everyday curriculum. This is not entirely surprising because "there is no common under- 
standing or agreement on the nature of STEM education as an integrated or multidisciplinary endeavor...Few guidelines and models exist for teachers to follow regarding how to teach using STEM integration approaches" (Roehrig, Moore, Wang, \& Park, 2012, p. 32). The response below is very similar to those of the other teachers' responses: STEM stands for Science, Technology, Engineering, and Math. STEM education is a way to include all four areas into what our students are learning. (Teacher A, School One, Interview, Jan. 17, 2013)

This teacher, along with the others who defined STEM education simply by defining the acronym, did not describe the teaching methods employed or types of lessons used to implement STEM education in the classroom.

\section{STEM Activities}

The STEM activities that the teachers did with their students further illustrate the teachers' definitions of STEM education. Again, "integration of STEM content areas through reading" appeared in five out of the seven interviews; the two teachers from School Three did not indicate reading about STEM as a STEM activity. Some teachers, however, gave examples of "hands-on science activities." Three out of the four teachers from School One indicated the use of FOSS kits for some science lessons. Similarly, three teachers also mentioned interactive websites and/or interactive computer programs in which students learn about a STEM topic through a game-like setup. Three teachers gave examples of their students creating, engineering, and/or experimenting. Below are examples of hands-on activities:

We did the Eco-Bot challenge...Students created an eco-bot robot out of a toothbrush, battery, wires, double sided tape, and they had to contain a toxic spill (bird seeds) without touching their robot. Then, calculate their robot's efficiency. Now, we are engineering egg vehicles that need to survive a crash test, so we're learning about Newton's Laws. (Teacher G, School Three, Interview, Jan. 15, 2013).

My class and the other fourth graders got to develop podcasts during their unit on erosion. Lots of research on their part, we went outside and did experiments with water and dirt, watched interactive videos on iPads, and the students each had to play the role of "scientist" for their podcast [recorded each other explaining a different part they each specialized in]. (Teacher E, School Two, Interview, Jan. $22,2013)$

These activities were coded as "hands-on activities" because the students played active roles in the learning process by creating, experimenting, calculating, and using various tools and resources in order to understand a concept. The teachers believed these activities were STEM activities because of the subject matter (science and/ or engineering, and math), the use of tools and materials, and the active engagement of students. It should also be noted that while Teacher A described a seemingly successful STEM activity, she mentioned that her STEM academy performed poorly in math on the Adequate Yearly Progress (AYP) assessments; therefore, her school's main focus is mathematics. STEM is taught as a single lesson once a week.

Another theme that emerged based on the repetition of its occurrence in the responses of five out of seven teachers was "student-led research on STEM topics." One teacher from School Two and a teacher from School Three did not mention students researching STEM topics as a STEM activity. Below are examples of responses from teachers who did mention student-led research.

We recently covered a STEM lesson based on scientific inventions [read about and viewed "virtual models" through a website] and how each has improved our lives today. Students had to research a particular invention and create a "virtual museum" on their laptops, in which all the rooms are like different slides in a Power Point. They were to find info for each area of STEM for their topic. (Teacher A, School One, Interview, Jan. 17, 2013). 
We just finished a Reading/Science unit on space. The students did research reports on a planet and a constellation (Teacher D, School One, Interview, Jan. 15, 2013)

These responses illustrate a lack of a unified interpretation of STEM education. Both teachers quoted indicated that the above were STEM lessons. The teachers assert these are STEM lessons because students read about and research science-related topics, thus covering the science, technology, engineering, and possibly mathematical topics, while creating a Power Point-type presentation on laptops-using technology.

Another emerging theme in the category of STEM activities includes "use of technology in any form." All three schools have laptops for students, including iPads and iPods, and Smart Boards in the classrooms. The teachers indicated the use of technology as a way to integrate STEM into the daily curriculum by allowing students to research, read, and/or write about STEM using the laptops. The teacher from School Three gave an example of a STEM activity in which technology was used in various forms:

We engineered rubber bank and soda straw rockets at the culmination of a science unit on the solar system and flight. We used our iPads and active board to research, and after flying the rockets, we measured the distances they traveled and graphed the distances. (Teacher F, School Three, Interview, Jan. $15,2013)$

This example shows that students had the opportunity to engineer and create, and to also explore and research using the newest technology available at their school. However, this demonstrates the need for more information to explore whether learning about technology qualifies as STEM education, or is using technology is STEM education. This again depends on the teachers' definitions of STEM education.

\section{STEM: Teachers' perspective of student reactions}

All seven teachers reported that students positively responded to STEM education. Each teacher indicated students are always engaged and interested in learning. Three teachers indicated the students like to work in groups, and two indicated enhanced memory and comprehension. Below is a response given by a teacher from School Three describing the students' response to the Eco-Bot Challenge:

It was amazing. There was full engagement, zero behavior problems, and really not much differentiating needed. It was nice that I could also take a step back from just standing there teaching, and have the students explore and do hands-on work that really got them understanding every aspect of the project. (Teacher G, School Three, Interview, Jan. 15, 2013)

Most teachers also indicated as the teacher above that hands-on activities in particular have the most positive effects on their students, from full engagement to a better grasp of the subject matter.

\section{STEM Planning}

In the category of STEM planning-or how the teachers plan STEM lessons-three themes emerged. The first theme was "STEM unit team planning." Five of the seven teachers explained that they typically collaborate with teachers who teach their respective grades in planning and creating unit lesson plans. A teacher from School Three explains the STEM unit planning process below:

We, so the other 4th grade teachers, create Project Based lessons (PBL) units and plan together as a grade level. We have a graphic organizer that allows us to document how each STEM component will be a part of the unit, and most of the time we take the lead on separate parts of STEM if we find we're more knowledgeable or comfortable in that aspect of it. (Teacher F, School Three, Interview, Jan. 15, 2013) 
Many teachers specified that while they work together to plan a STEM unit, each teacher may feel more comfortable taking the lead on a specific STEM content area because of his/her background, schooling, or experience. This emerged as another theme coded as "specific STEM area expertise."

The teachers also specified that they use the project-based learning (PBL) units, as well as taking Common Core State Standards (CCSS) and their schools' various kits (FOSS kits for science, Lead 21 for reading) into consideration when planning a STEM unit. Some teachers also referred to various subjects separately such as math and reading:

Usually math is correlated although it should be incorporated into daily curriculum. I will incorporate it where and if it fits in...Language Arts, Science, and Social Studies are usually broad fields. Our reading program is set up by units. One unit is Science; the next is Social Studies which usually correlate with CCSS $4^{\text {th }}$ grade. (Teacher D, School One, Interview, Jan. 15, 2013)

Some teachers indicated the use of their school's curriculum to use as a guide for the planning of STEM lessons. Below is another response on the planning process:

We plan for STEM lessons by looking at our Math, Reading, Science, and Social Studies curriculum. So that means using Lead 21 (our reading program) and FOSS kits. We also look at our unit of study that we created. When looking at everything that we are working on, we can combine concepts and incorporate into our Reading or Math block. (Teacher B, School One, Interview, Jan. 17, 2013)

This is coded as "identify common concepts within curriculum." The teachers use a number of tools at their disposal to aid in their STEM lesson planning, as specified. While only three teachers indicated they turn to their school's STEM coordinators for help in planning and for lesson demonstrations, in the next categorySTEM Resources-this theme will be more prominent.

\section{STEM Resources}

When asked what or where they turn to for extra help in teaching STEM, the teachers listed many similar resources. Five out of the seven teachers said that if they need further STEM-related information, they first do research on their own by searching the Internet. This theme is coded as "Internet for STEM-related news and lesson ideas." While they did not go into detail about the websites they preferred, one teacher from School Three said the following:

I pay attention to the news and turn to either science, engineering associations or organizations as well as their websites. For example, the American Civil Engineers, or NSTA. Our school also has community partners, like Women in Engineering, and I've had a 4-H club come in to present the Eco-Bot project, which helped me in planning lessons around the entire project. But there really aren't a lot of resources out there on STEM. (Teacher G, School Three, Interview, Jan. 15, 2013)

Aside from the Internet, this teacher also generates ideas for STEM lessons from organizations which specialize in the STEM fields. When the teachers need immediate help with a STEM lesson or do not find what they need on the Internet-which is common, as mentioned by the previous teacher that there are limited resources available on STEM education-they turn to their STEM coordinators. All seven teachers indicated they utilize the expertise of the STEM coordinators at their schools. This theme is coded as "STEM coordinators for planning and lesson demonstrations." Two teachers said the following about their school's STEM coordinators: 
I usually go to one of our STEM coaches, because they are the "experts" and always make themselves available to us and offer great ideas and support. (Teacher D, School One, Interview, Jan. 15, 2013)

Our STEM coordinator is very useful if we need any help in planning a lesson, gathering materials, or seeking out some help from our partners who many times have great ideas for us and even do demonstrations or presentations for us if we'd like them to. (Teacher E, School Two, Interview, Jan. 22, 2013)

Most notably, the teachers said that STEM coordinators are a base of knowledge in the STEM content areas, offer ideas teachers can utilize, aid in lesson and unit planning, offer guidance on the materials available for activities, and demonstrate lessons teachers may be unsure of approaching.

\section{STEM Support}

The question in this category was based on the support the school provided in the teaching of STEM. Again, STEM coordinators were mentioned here by four teachers in relation to the support their school offers teachers in STEM education. This theme was coded as "STEM coordinators for support."

Five of the teachers also said that "technology for student use" is supportive of the implementation of STEM education. School One supplies its students with laptops and iPads. School Three has wireless notebooks, iPads, iPods, and all of the schools have Smart Boards. A teacher from School One was particularly enthusiastic about the support in his school:

Our school supports STEM teaching by giving us access to 1:1 laptops, active votes, iPads, and any other technology we can get our hands on. This all helps with STEM. Our school supports us with Science kits and other resources in the STEM lab. Our STEM coordinators run the lab. There is a ton of support for STEM at our school! (Teacher B, School One, Interview, Jan. 17, 2013)

The teachers all agreed that the technology is useful for daily activities, specifically pertaining to STEM education. Students use the technology to research STEM topics, read and write about STEM topics, create presentations on their findings, and use interactive websites to learn about STEM. Three of the teachers also indicated that their schools offer professional development opportunities in the form of trainings. Another teacher from School One described the professional development opportunities in the most detail:

Our school provides us with ample opportunities for professional development and Common Core training - we've had a lot of inquiry and PBL training, which is very useful in teaching STEM. (Teacher A, School One, Interview, Jan. 17, 2013)

"Trainings in teaching methods" includes training in PBL unit planning and instruction, CCSS planning and implementation of standards, inquiry-based learning, and STEM education. These are viewed as useful for teachers in not only the STEM education aspect of teaching, but for teaching in general.

\section{Discussion \& Conclusion}

The research findings support the conclusions discussed in the literature review (Breiner, Harkness, Johnson, \& Kolker, 2012) that teachers, including STEM academy teachers, do not share a common understanding of STEM education. Definitions and perceptions of STEM education are varied, as are teacher perceptions of integration. The teachers interviewed viewed STEM education as involving integration of subjects. This view is consistent with Brown, Brown, Reardon \& Merrill (2011) definition of STEM as an integrated approach to teaching and learning. Their descriptions of how STEM integration was implemented varied among the teachers. A majority of the teachers interviewed primarily spoke about activities involving reading about 
and researching STEM topics as an integral part of their STEM curricula. However, the basic premise of STEM education is described as more inquiry and project-based rather than lecture-based (Breiner et al., 2012). Though, some of these teachers did give examples of hands-on activities that integrated STEM concepts in a project-based fashion, reporting several positive results from these types of activities. The teacher from School Two described an outdoor, exploration STEM unit on erosion that corresponded with her school's definition of STEM education.

Most teachers also believe that the use of technology, such as a laptop, meet the requirements of integrating the 'T' in STEM education. School One's definition of STEM education specifically indicates that the technology component of STEM includes the "making and use of tools, machines, etc." (2012), but the teachers only discussed the use of technology. Furthermore, some proponents of STEM believe that that the technological aspect also includes technology concepts, or learning about technology, rather than simply using technology (Brown et al., 2011).

One teacher pointed out that even though students were engaged in the STEM integrated lessons, their school performed poorly in math and they decided to focus on helping students in mathematics the next year. This raises questions on how does a teacher integrate subjects while insuring rigorous disciplinary content is taught? Furthermore, NSTA (Brown et al, 2011) does emphasize that a successful STEM program helps prepare students in disciplinary competencies and skills in the four disciplines. Their definition of STEM emphasizes carefully designed instructional sequences that build on each other with connections to real world applications.

STEM academy teachers largely favor planning for STEM lessons with other teachers to create a unit. This is regarded as a resourceful way to create STEM lessons using each teacher's strengths and expertise. The joint planning also provides opportunities to carefully sequence lessons. The teachers also indicated a lack of resources for STEM education. This is not surprising considering the push for STEM in schools is a relatively new movement. STEM coordinators are helpful resources for teachers. Aside from STEM coordinators though, most of the teachers indicated that they do research on the Internet to find STEM-related news or lesson plans. The Internet does not always provide high-quality, verifiable information, however, so this can lead to both a misunderstanding of STEM content and the implementation of ineffective lessons.

Lastly, in terms of support, the STEM academy teachers each agreed that updated technology that is readily accessible to students is important in facilitating the goals of STEM education. Most of their lessons center on the use of technology in one form or another. In addition, some teachers mentioned the usefulness of professional development opportunities provided by their school. Trainings in inquiry-based and PBL methods as well as Common Core were viewed as positive learning experiences for the teachers as they attempt to implement STEM education.

\section{Implications}

STEM education lacks a clear definition, and most importantly research is lacking on how to implement STEM in elementary schools. A unified understanding of a STEM program will be helpful for developing high quality STEM elementary schools. Elementary teachers are responsible for teaching multiple disciplines. Therefore, teachers need access to high quality materials that provide meaningful learning experiences for students while ensuring rigorous STEM content is taught. Simply integrating STEM subjects is not enough. Ensuring that rigorous content is taught through careful sequencing and efficient use of instructional time is important. Teachers need to have an understanding of how to support students to understand rigorous STEM content and practices as outlined in the documents such as the Next Generation Science Standards (NGSS, 2012), and the Common Core Mathematics Standards (National Governors Association Center for Best Practices \& Council of Chief State School Officers, 2010). Further research is needed to refine and develop models of STEM elementary schools that support high quality learning experiences. Supports for teachers such as materials, and access to high quality professional development is needed. 


\section{Limitations}

The limitations of this study are the small sample size of 7 teachers from 3 STEM schools. Furthermore, the paper is based on teacher interviews as opposed to observations of actual classroom lessons. We were interested in understanding how teachers perceive and plan STEM lessons. Therefore, further studies involving classroom observations would be helpful to study how these STEM lessons are enacted.

\section{Acknowledgements} interviews.

We like to thank the teachers who participated in the study. The second author conducted the teacher

\section{References}

Bluford STEM Academy (2013). Retrieved from http://www.gcsnc.com/education/components/scrapbook/default.php?sectiondetailid $=3504768$.

Breiner, J. M., Harkness, S. S., Johnson, C. C., \& Koehler, C. M. (2012). What is STEM? A discussion about conceptions of STEM in education and partnerships. School Science and Mathematics, 112(1), 3-11. doi: 10.1111/j.1949-8594.2011.00109.x.

Brown, R., Brown, J., Reardon, K., \& Merrill, C. (2011). Understanding STEM: Current perceptions.Technology and Engineering Teacher, 70(1), 5-9. Retrieved from http://www.iteaconnect.org/ Publications/ TTTarticleindex13.htm.

Committee on Highly Successful Schools or Programs in K-12 STEM Education, \& National Research Council (2011). Successful k-12 STEM education: Identifying effective approaches in science, technology, engineering, and mathematics. Retrieved from http://www.nap.edu/catalog.php? record_id=13158.

Committee on Science, Technology, Engineering, and Math Education (2011). The federal science, technology, engineering, and mathematics (STEM) education portfolio. Retrieved from http://www.whitehouse. gov/sites/default/files/microsites/ostp/costem federalstem education portfolio report.pdf.

Eberle, F. (2010). Why STEM education is important. InTech. Retrieved from

http://www.isa.org/InTechTemplate.cfm?template=/ContentManagement/ContentDipl ay.cfm \&ContentID=83593.

Gerlach, J. (2012). STEM: Defying a simple definition. NSTA Reports. Retrieved from http:/www.nsta. org/ publications/news/story.aspx?id=59305

Hanushek, E. A., Peterson, P. E., \& Woessmann, L. (2011). Teaching math to the talented. Education Next, 11(1),11-18. Retrieved from http://educationnext.org/teaching-math-to-the-talented/

National Governors Association Center for Best Practices \& Council of Chief State School Officers. (2010). Common Core State Standards for Mathematics. Washington, DC: Authors.

NGSS Lead States. (2013). Next Generation Science Standards: For states, by states. Washington, DC: The National Academies Press.

National Math and Science Initiative (2012). Why STEM education matters. University of Notre Dame'sInstitute for Educational Initiatives. Retrieved from http://iei.nd.edu/assets/78206/why stem education matters.pdf.

National Research Council of the National Academies of Science (2011). Conceptual framework for new science education standards. Retrieved from http://www.http://books.nap.edu/catalog. php?record_id=13158 
Roehrig, G. H., Moore, T. J., Wang, H., \& Park, M. S. (2012). "Is adding the E enough? Investigating the impact of k-12engineering standards on the implementation of STEM integration." School Science and Mathematics, 112, 31-44.

Stone, J.R., III, Alfeld, C., and Pearson, D. (2008). Rigor and relevance: Testing a model of enhanced math learning in career and technical education. American Education Research Journal, 45(3), 767-795.

U.S. Department of Labor (2007). The STEM workforce challenge: The role of the public workforce system in a national solution for a competitive science, technology, engineering, and mathematics (STEM) workforce. Washington, DC: Author. Retrieved from http://www.doleta.gov/youth services/pdf/STEM Report 4\%2007.pdf.

West Hills STEM Academy (2013). Retrieved from http://www.bremertonschools.org/Domain/897.

Young, V.M. (2011). Inclusive STEM schools: Early promise in Texas and unanswered questions. Paper prepared for the workshop of the Committee on Highly Successful Schools or Programs for K-12STEM Education, National Research Council, Washington, DC, May 10-12, 2011. 


\section{Appendix A}

Table 1

Sample of Coded Teacher Responses

\begin{tabular}{|c|c|c|c|c|c|c|c|}
\hline Category & $\begin{array}{l}6^{\text {th }} \text { grade } \\
\text { School one }\end{array}$ & $\begin{array}{l}6^{\text {th }} \text { grade school } \\
\text { one }\end{array}$ & $\begin{array}{l}5^{\text {th }} \text { grade school } \\
\text { one }\end{array}$ & $\begin{array}{l}4^{\text {th }} \text { grade school } \\
\text { one }\end{array}$ & $\begin{array}{l}4^{\text {th }} \text { grade school } \\
\text { two }\end{array}$ & $\begin{array}{l}4^{\text {th }} \text { grade school } \\
\text { three }\end{array}$ & $\begin{array}{l}5^{\text {th }} \text { grade school } \\
\text { three }\end{array}$ \\
\hline $\begin{array}{l}\text { STEM teacher } \\
\text { perception }\end{array}$ & $\begin{array}{l}\text { Inclusion of all } \\
4 \text { areas } \\
\text { Integration of } \\
\text { STEM topics }\end{array}$ & $\begin{array}{l}\text { Integration of } \\
\text { STEM topics } \\
\text { Integration of } \\
\text { science into } \\
\text { everyday cur- } \\
\text { riculum } \\
\text { Everyday use of } \\
\text { technology } \\
\underline{\text { Integration of }} \\
\underline{\text { STEM content }} \\
\underline{\text { areas into }} \\
\underline{\text { reading }}\end{array}$ & 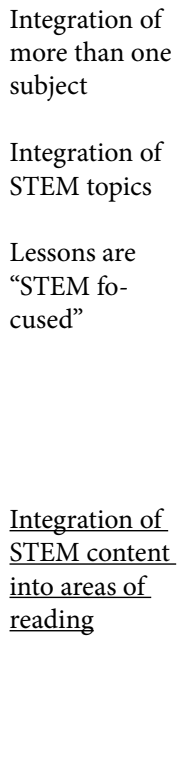 & $\begin{array}{l}\text { Integration of } \\
\text { STEM subjects }\end{array}$ & $\begin{array}{l}\text { STEM fields } \\
\text { not taught in } \\
\text { isolation } \\
\text { Integrating } \\
\text { cognitively } \\
\text { demanding } \\
\text { standards-based } \\
\text { instruction } \\
\text { STEM focus } \\
\text { throughout the } \\
\text { day } \\
\underline{\text { Integration of }} \\
\underline{\text { STEM Content }} \\
\underline{\text { into reading }}\end{array}$ & $\begin{array}{l}\text { School contexts } \\
\text { provides di- } \\
\text { lemma (need to } \\
\text { improve math } \\
\text { scores) } \\
\text { Student lead } \\
\text { hands-on ac- } \\
\text { tivities (teacher } \\
\text { monitors) }\end{array}$ & $\begin{array}{l}\begin{array}{l}\text { No discipline } \\
\text { should domi- } \\
\text { nate over others }\end{array} \\
\text { Increase stu- } \\
\text { dent interest in } \\
\text { STEM careers } \\
\text { (gov goal) } \\
\text { Integra- } \\
\underline{\text { tion of STEM }} \\
\underline{\text { content areas }} \\
\underline{\text { into reading }}\end{array}$ \\
\hline \multirow[t]{6}{*}{$\begin{array}{l}\text { STEM } \\
\text { Activities }\end{array}$} & $\begin{array}{l}\text { Reading about } \\
\text { STEM topics }\end{array}$ & $\frac{\text { Reading about }}{\underline{\text { STEM topics }}}$ & $\frac{\text { Reading about }}{\underline{\text { STEM topics }}}$ & $\begin{array}{l}\text { Reading about } \\
\underline{\text { STEM topics }}\end{array}$ & & & \\
\hline & $\begin{array}{l}\frac{\text { Student-led }}{\text { research on }} \\
\underline{\text { STEM topics }} \\
\text {-presentation }\end{array}$ & $\frac{\frac{\text { Student-led }}{\text { research on }}}{\frac{\text { STEM topics }}{\text { (writing) }}}$ & $\begin{array}{l}\frac{\text { Student-led }}{\text { research on }} \\
\underline{\text { STEM topics }} \\
\text { (writing) }\end{array}$ & $\begin{array}{l}\underline{\text { Student led }} \\
\underline{\text { research on }} \\
\underline{\text { STEM topics }}\end{array}$ & & $\begin{array}{l}\underline{\text { Student-led }} \\
\underline{\text { research on }} \\
\underline{\text { STEM topics }}\end{array}$ & $\begin{array}{l}\text { Science com- } \\
\text { munity demon- } \\
\text { strations }\end{array}$ \\
\hline & $\begin{array}{l}\underline{\text { Hands-on sci- }} \\
\underline{\text { ence activities }}\end{array}$ & $\begin{array}{l}\text { Hands on sci- } \\
\text { ence activities. }\end{array}$ & $\underline{\text { Hands on sci- }}$ & & & & \\
\hline & $\begin{array}{l}\text { Use of technol- } \\
\text { ogy in any form } \\
\text { (interactive } \\
\text { websites) }\end{array}$ & $\begin{array}{l}\text { Use of technol- } \\
\text { ogy in any form } \\
\text { (presentation } \\
\text { interactive } \\
\text { computer } \\
\text { programs) }\end{array}$ & $\begin{array}{l}\frac{\text { Use of technol- }}{\text { ogy in any form }} \\
\text { (presentation) } \\
\text { Math to under- } \\
\text { stand engineer- } \\
\text { ing careers }\end{array}$ & $\begin{array}{l}\text { Use of technol- } \\
\text { ogy in any form } \\
\text { Math \& science } \\
\text { integrated } \\
\text { Math taught } \\
\text { alone (correlat- } \\
\text { ed) }\end{array}$ & $\begin{array}{l}\underline{\text { Hands on sci- }} \\
\text { ence activities } \\
\text {-experiments } \\
\text { Use of technol- } \\
\text { ogy in any form } \\
\text { (Developing } \\
\text { podcasts, inter- } \\
\text { active videos on } \\
\text { iPads, Active } \\
\text { Board) }\end{array}$ & $\begin{array}{l}\text { Hands-on sci- } \\
\text { ence activities } \\
\text { (engineered } \\
\text { rockets) } \\
\text { Use of technolo- } \\
\text { gy in any form } \\
\text { (iPads, Active } \\
\text { Board) }\end{array}$ & $\begin{array}{l}\text { STEM taught } \\
\text { once a week } \\
\text { Science com- } \\
\text { munity demon- } \\
\text { strations }\end{array}$ \\
\hline & & & & $\begin{array}{l}\text { ELA, Science, } \\
\text { social studies } \\
\text { taught together } \\
\text { (Broad fields) }\end{array}$ & $\begin{array}{l}\text { Math explo- } \\
\text { rations of real } \\
\text { situations }\end{array}$ & $\begin{array}{l}\text { Measure dis- } \\
\text { tances } \\
\text { Plot graphs }\end{array}$ & $\begin{array}{l}\text { Engineering } \\
\text { and creating }\end{array}$ \\
\hline & & & & & $\begin{array}{l}\text { Outdoor activ- } \\
\text { ities }\end{array}$ & $\begin{array}{l}\text { Measure dis- } \\
\text { tances } \\
\text { Plot graphs }\end{array}$ & $\begin{array}{l}\text { School context } \\
\text { provides di- } \\
\text { lemma (need to } \\
\text { improve math } \\
\text { scores) }\end{array}$ \\
\hline
\end{tabular}

Note: This table represents how data was coded from the teacher interviews. The underlined text represents commonalities among teacher responses. 


\section{Appendix B}

\section{Interview Questions}

Please answer the following questions using your own opinions and experiences.

1. What is STEM education? (Define it in your own words.)

2. How do you teach STEM in your classroom?

3. Has your school outlined criteria for or encouraged teaching STEM? If yes, explain.

4. How does your school support teaching of STEM?

5. What resources do you use for teaching STEM?

6. What kinds of support and resources do you need to teach stem?

7b. What/where do you turn to for extra help, if you seek it?

9. Do you know what started the push for STEM (whether nationally or at your school)?

10. What do you think the future of STEM is in Nevada schools (or your school?) 